\title{
Managing Stormwater by Accident: A Conceptual Study
}

\author{
Carly M. Maas ${ }^{1,2, * \mathbb{D}}$, William P. Anderson, $\mathrm{Jr}^{3}{ }^{3} \mathbb{D}$ and Kristan Cockerill ${ }^{4}(\mathbb{D})$ \\ 1 Department of Geology, University of Maryland, College Park, MD 20742, USA \\ 2 Earth System Science Interdisciplinary Center, University of Maryland, College Park, MD 20742, USA \\ 3 Department of Geological and Environmental Sciences, Appalachian State University, Boone, NC 28608, USA; \\ andersonwp@appstate.edu \\ 4 Department of Interdisciplinary Studies, Appalachian State University, Boone, NC 28608, USA; \\ cockerillkm@appstate.edu \\ * Correspondence: maascm@umd.edu
}

Citation: Maas, C.M.; Anderson, W.P., Jr.; Cockerill, K. Managing Stormwater by Accident: A Conceptual Study. Water 2021, 13, 1492. https://doi.org/10.3390/ w13111492

Academic Editor: C. Radu Gogu

Received: 26 April 2021

Accepted: 24 May 2021

Published: 26 May 2021

Publisher's Note: MDPI stays neutral with regard to jurisdictional claims in published maps and institutional affiliations.

Copyright: (c) 2021 by the authors. Licensee MDPI, Basel, Switzerland. This article is an open access article distributed under the terms and conditions of the Creative Commons Attribution (CC BY) license (https:// creativecommons.org/licenses/by/ $4.0 /)$.

\begin{abstract}
Stormwater-driven road salt is a chronic and acute issue for streams in cold, urban environments. One promising approach for reducing the impact of road salt contamination in streams and adjacent aquifers is to allow "accidental wetlands" to flourish in urban areas. These wetlands form naturally as a byproduct of human activities. In this study, we quantified the ability of an accidental wetland in northwestern North Carolina, USA, to reduce the timing and peak concentration of road salt in a stream. Monitoring suggests that flow and transport processes through the wetland reduce peak concentrations and delay their arrival at the adjacent stream. We expand these findings with numerical simulations that model multiple meltwater and summer storm event scenarios. The model output demonstrates that small accidental wetland systems can reduce peak salinities by $94 \%$ and delay the arrival of saltwater pulses by 45 days. Our findings indicate that accidental wetlands improve stream water quality and they may also reduce peak temperatures during temperature surges in urban streams. Furthermore, because they find their own niche, accidental wetlands may be more effective than some intentionally constructed wetlands, and provide opportunities to explore managing stormwater by letting nature take its course.
\end{abstract}

Keywords: accidental wetland; road salt; urban hydrogeology; headwater stream

\section{Introduction}

The idea of "accidental" wetlands is gaining traction as a potentially valuable component of various ecosystems. These are water bodies that "result from human activities, but are not designed or managed for any specific outcome" [1]. As the moniker implies, these "accidental" systems arise on their own, often in vacant lots or various low spots where stormwater or irrigation runoff collect. In a study of the South Platte River basin, for example, $89 \%$ of the extant wetlands exist because of various irrigation conveyances [2]. Accidental wetlands typically form in low-lying abandoned or underutilized landscapes with poor drainage [3]. Flooding often occurs in these areas due to a lack of stormwater management and sediment transport processes, which contribute to repeated sediment deposition, allowing wetland plants to grow and establish a habitat [3]. Brooks et al. [4] documented that in arid, urban areas, effluent from human sources can account for up to $90 \%$ of streamflow during dry periods. Any wetland-like areas on those rivers exist because of human activity. Although they are not yet heavily studied, there is evidence that these accidental wetlands offer benefits to rival constructed versions $[1,5,6]$. In fact, Palta et al. [3] argue that "accidental wetlands may provide more services than designed environments because the latter are commonly over-designed for a limited set of specific functions." There is also evidence that small wetlands, which many accidental wetlands are, can be as or more effective than larger ones [7,8]. Although they are just beginning to be intentionally documented and studied, Palta et al. [3] offer evidence highlighting the ubiquity of accidental wetlands and their potential to offer diverse benefits. In the 
limited literature available, researchers have found that accidental wetlands can remove pollutants, mitigate heat, store groundwater, restore surface-mined lands, and provide the social benefits of additional green space in urban settings [3,9-11].

In these few known studies, accidental wetlands were shown to help with pollutant remediation, and a key pollutant in cold urban areas is road salt. Like accidental wetlands, in recent years researchers have paid increasing attention to de-icing salt in stormwater runoff as a key issue for stream quality, especially in urban areas. Although there are numerous salt sources in urban environments, including water-softening, septic field discharge, natural rock weathering, and wastewater treatment plants [12], the dominant source is road salt applied to the road surface in order to melt snow and ice [13,14]. The annual road salt application in the United States in 2014 was about 56.5 million metric tons, costing about $\$ 1.18$ billion [15]. Elevated salt levels in waterways contribute to negative consequences, including contaminating drinking wells [16] and various ecosystem impacts. In their review of the literature, Hintz and Relyea [17] found that salt negatively affects all freshwater species, but that the level at which salt becomes a concern is highly variable across species.

There are complex relationships between surface and groundwater systems, such that salt remains available for long periods of time as it travels between surface and groundwater systems [18-20]. Furthermore, numerous studies have focused on how effective various "green infrastructure" (e.g., rain gardens, bioretention systems) are in cold climates (see Kratky et al. [21] for a review). Retention systems capture salt as it runs off and can slow its path to waterways $[18,22]$. Retention systems do not, however, eliminate salt or retain it for long periods. Studies have found that salinity remains a key stream stressor even in restored streams and in those with stormwater management efforts in place [23,24]. In addition to its own negative consequences, salt can mobilize various metals and lower plants' uptake of metals, thereby reducing the effectiveness of bioretention [21,25-27]. Cockerill et al. [20], however, did find that retention had the potential to reduce salinity spikes, which can reduce the long-term salt levels in a given hydrologic system. Flattening the curve, as it were, and alleviating those salt spikes, may over time lower the summer pulses of salt into that system. Given Hintz and Relyea's [17] findings on the variability in how much salt triggers negative consequences, reducing salinity spikes and reducing summer inputs may reduce the effects on some aquatic species.

Although researchers are studying accidental wetlands and the negative effects of road salt on urban waterways, as far as we know, these two subjects have not been assessed in concert. We offer a conceptual study addressing the potential for accidental wetlands to ameliorate salinity levels. Because constructed wetlands offer highly variable results depending on scale, lifespan, and local hydrologic conditions [28-31], paying more focused attention to sites where wetlands form themselves may offer a cheaper and equally or more effective alternative means of lessening road salt impacts. Though no wetland will completely remove the salt from an urban stream system, there is still potential to improve urban water quality by documenting and encouraging accidental wetlands.

The project documented here is a testimony to the value of paying attention to local environments and the role of serendipity in research. Copeland [32] describes serendipity in science as "the intersection of chance and wisdom" and notes that the value of the serendipitous process or event can only be assessed in hindsight. In our case, authors Anderson and Cockerill initially noticed a "wetland" forming in a concrete culvert on the Appalachian State University campus and joked about its potential value. As we continued to observe the accumulation of sediment and increased vegetation, we began thinking that the site actually warranted more focused attention. At that point, author Maas was seeking a project and began to intentionally explore the effect of that wetland on road salt contamination for a headwater stream in an urban setting. In searching for background information to guide this more intentional study, we encountered the premise of "accidental wetlands" and recognized that we had one. 
Once intentionality was established, this study focused on these research questions:

1. Can flow through the shallow subsurface and chloride transport processes through accidental wetlands reduce the magnitude of saline peaks arriving at an adjacent stream?

2. Can flow through the shallow subsurface and chloride transport processes through accidental wetlands delay the arrival of a salt plume at an adjacent stream?

\section{Site Description}

Boone Creek and the accidental wetland investigated in this study are located in the small yet heavily urbanized town of Boone, North Carolina (Figure 1). Boone Creek is a headwater tributary of the South Fork New River, located within the Blue Ridge Mountains of northwestern North Carolina [20]. The town of Boone has high runoff ratios that result in flashy, flood-prone streams due to heavy urbanization near the stream. Although the total catchment area has $24.3 \%$ impervious surface cover, much of the more natural land use occurs on the mountain slopes near the catchment boundaries (Figure 2). Within $25 \mathrm{~m}$ of Boone Creek, the impervious surface cover ranges from $1 \%$ to $75 \%$ [33]. The Town of Boone has about 19,500 residents (U.S. Census Bureau, Quick Facts, https: / / www.census.gov / quickfacts / fact/table/boonetownnorthcarolina,US/PST045219, accessed 25 May 2021) and Appalachian State University (ASU) adds an additional 20,000 students to the local population (Appalachian State University Facts, https: / / www.appstate.edu/about/ accessed on 25 May 2021). The stream is in a mountainous area, with a total catchment relief of nearly $500 \mathrm{~m}$, although the main channel gradient is fairly low, at $2 \%$. The stream has previously had trout populations and retains a state classification as a "trout stream" [34]. Other tributaries to Boone Creek have gradients of greater than $10 \%$. The catchment of the basin considered in this study has an area of $5.2 \mathrm{~km}^{2}$ [20].

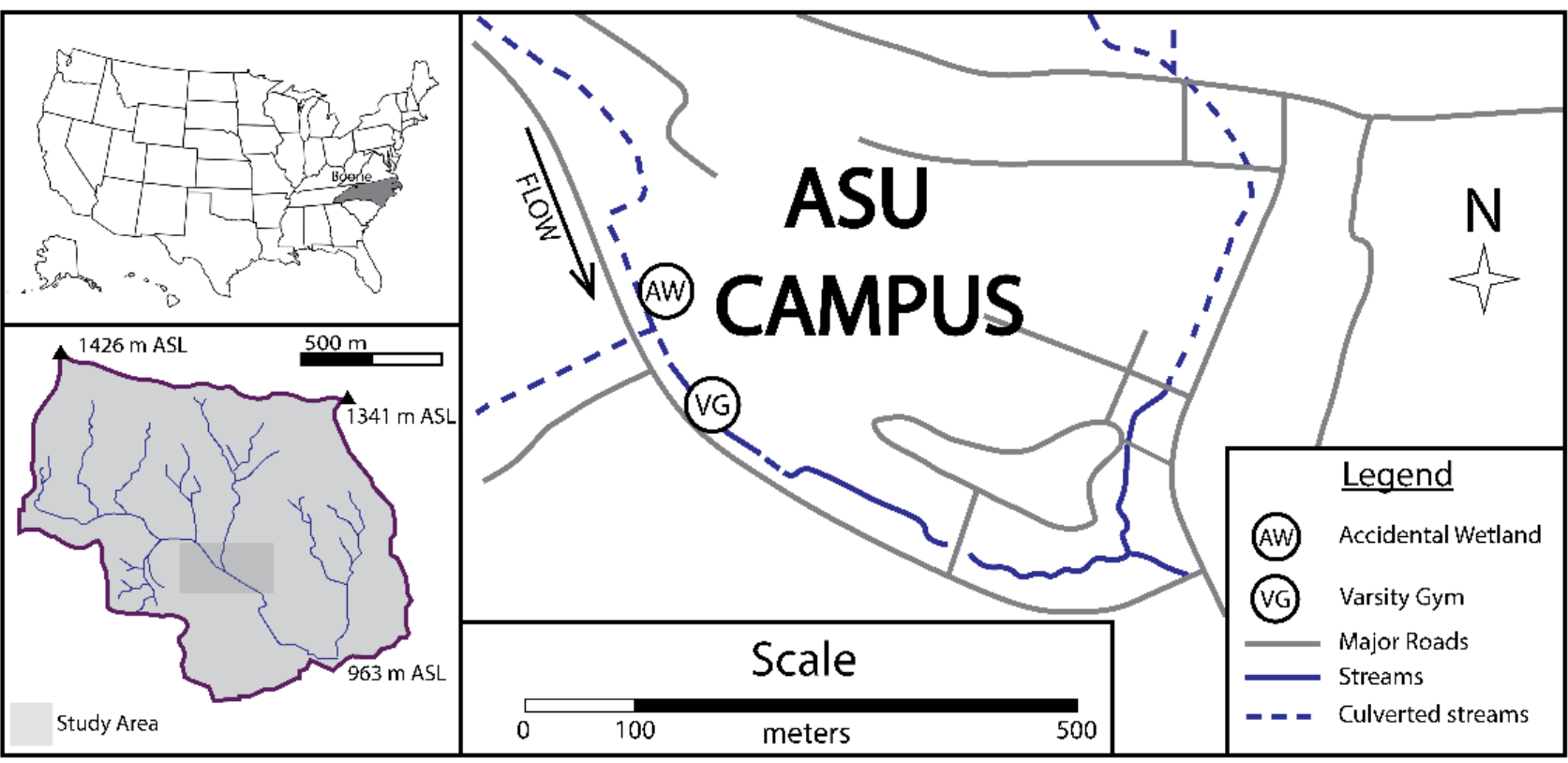

Figure 1. The Accidental Wetland (AW) site is located in Boone, North Carolina, USA (left top insert map) at $36^{\circ} 12^{\prime} 54.6^{\prime \prime} \mathrm{N}$ $81^{\circ} 40^{\prime} 57.0^{\prime \prime} \mathrm{W}$. The solid blue line denotes the surface water of Boone Creek and the dashed blue line signifies culverted sections of Boone Creek. The circles indicate data collection sites, Accidental Wetland (AW) and Varsity Gym (VG). The bottom left insert map shows the Boone Creek watershed (heavy purple line) with the black triangles indicating peak elevations within the watershed. The arrow represents the direction of flow. ASL denotes above sea level. Adapted from ref. [20]. 


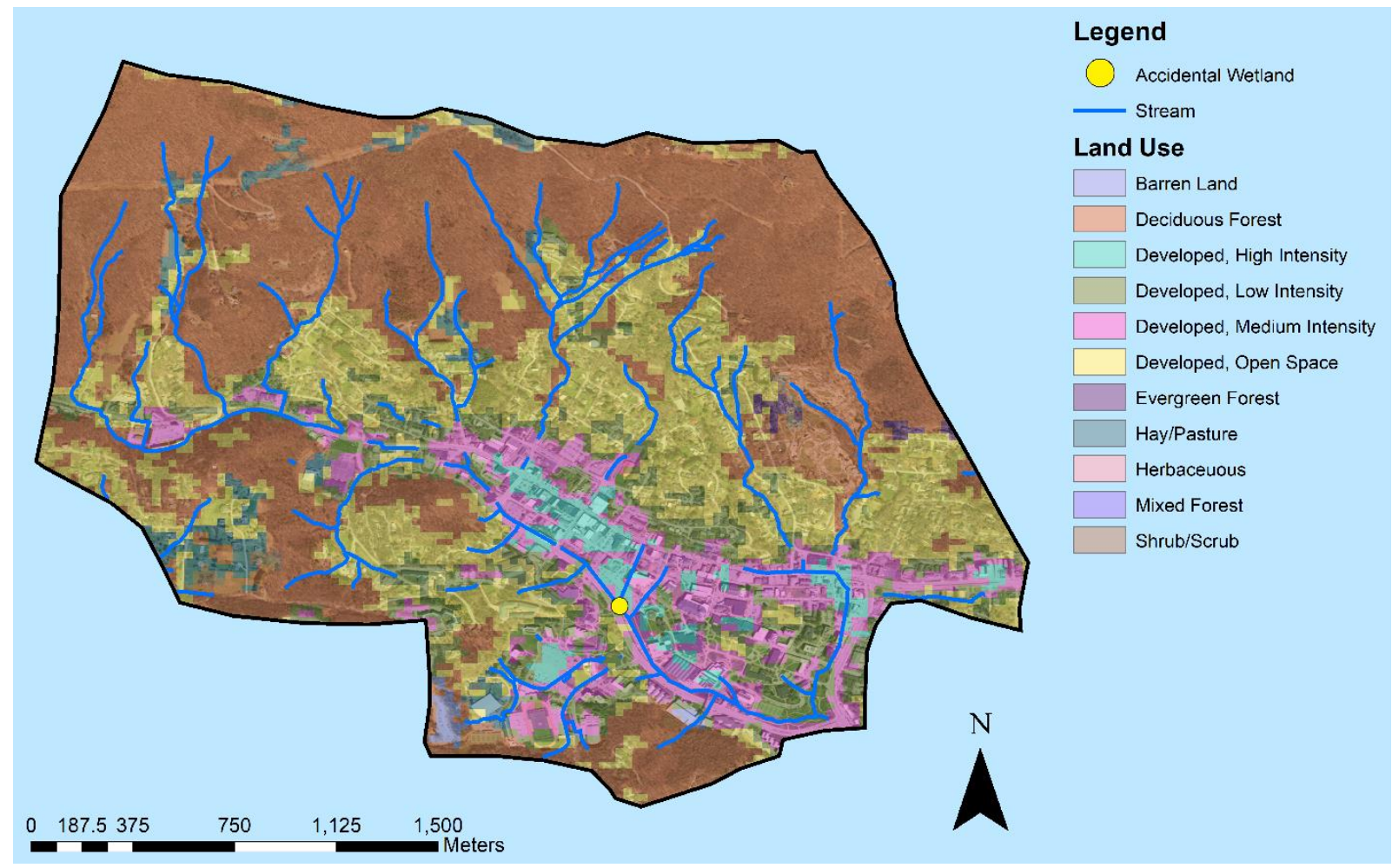

Figure 2. Land use map of the Boone Creek watershed. The Accidental Wetland site is located in the light blue and pink regions, which designate medium and high intensity development, respectively. The stream includes culverted and nonculverted segments. The map was created using ArcGIS ${ }^{\circledR}$ software by Esri, Redlands, CA, USA. Accessed on 10 February 2021. ArcGIS ${ }^{\circledR}$ and ArcMap ${ }^{\mathrm{TM}}$ are the intellectual property of Esri and are used herein under license. Copyright $\odot$ Esri. All rights reserved. For more information about Esri ${ }^{\circledR}$ software, please visit www.esri.com, accessed on 10 February 2021.

Boone Creek (Figure 1) runs through several culverts, with the longest being about $600 \mathrm{~m}$ long [20]. The area experiences $89 \mathrm{~cm}$ of snow per year, requiring $6 \times 10^{5} \mathrm{~kg}$ (600 metric tons) of deicing salt applied to the impervious surfaces on average annually [12]. Electrical conductivity data, converted to equivalent chloride, indicate that the stream regularly violates the US Environmental Protection Agency's (EPA) chronic threshold of a four-day average chloride concentration, exceeding $230 \mathrm{mg} / \mathrm{L}$, and also exceeds the acute threshold of a one-hour average chloride concentration, exceeding $860 \mathrm{mg} / \mathrm{L}$ on a regular basis in the winter salting season [20,35]. Between 1 July 2014 and 1 July 2015, Boone Creek exceeded the EPA's chronic threshold for $10 \%$ of the time, or 36 days, and exceeded the acute threshold for the equivalent of 8.5 days [20].

Our accidental wetland site is unique because it was created in a constrained concrete channel and did not form on an existing substrate. Subsequently, there is no direct connection between the wetland and the natural groundwater reservoir. We are treating the accidental wetland as an isolated "aquifer" that is disconnected from the natural groundwater flow system. Throughout the rest of this paper, our references to groundwater flow and solute transport are solely related to this process in the small accidental wetland that formed in the concrete culvert that ultimately feeds water to Boone Creek through seepage at its downgradient end. The only sources of water to the accidental wetland are from runoff from impervious surfaces or direct precipitation. Figure 3 shows the total area of the drainage basin to the accidental wetland, delineating pervious areas and impervious areas, such as buildings and sidewalks. The 30-year normal precipitation in Boone as measured at the BOONE 1 SE, NC US weather station between 1981 and 2010 is $1338 \mathrm{~mm}$, with roughly equal precipitation during each season (https:/ / www.ncdc.noaa.gov/cdo-web/datatools/normals, accessed on 21 April 2021). As Figure $4 \mathrm{a}-\mathrm{f}$ show, the $600 \mathrm{~m}$ culvert containing Boone Creek is open for five meters to 
allow stormwater to enter from a concrete conveyance that drains part of campus, as well as part of the Town of Boone.

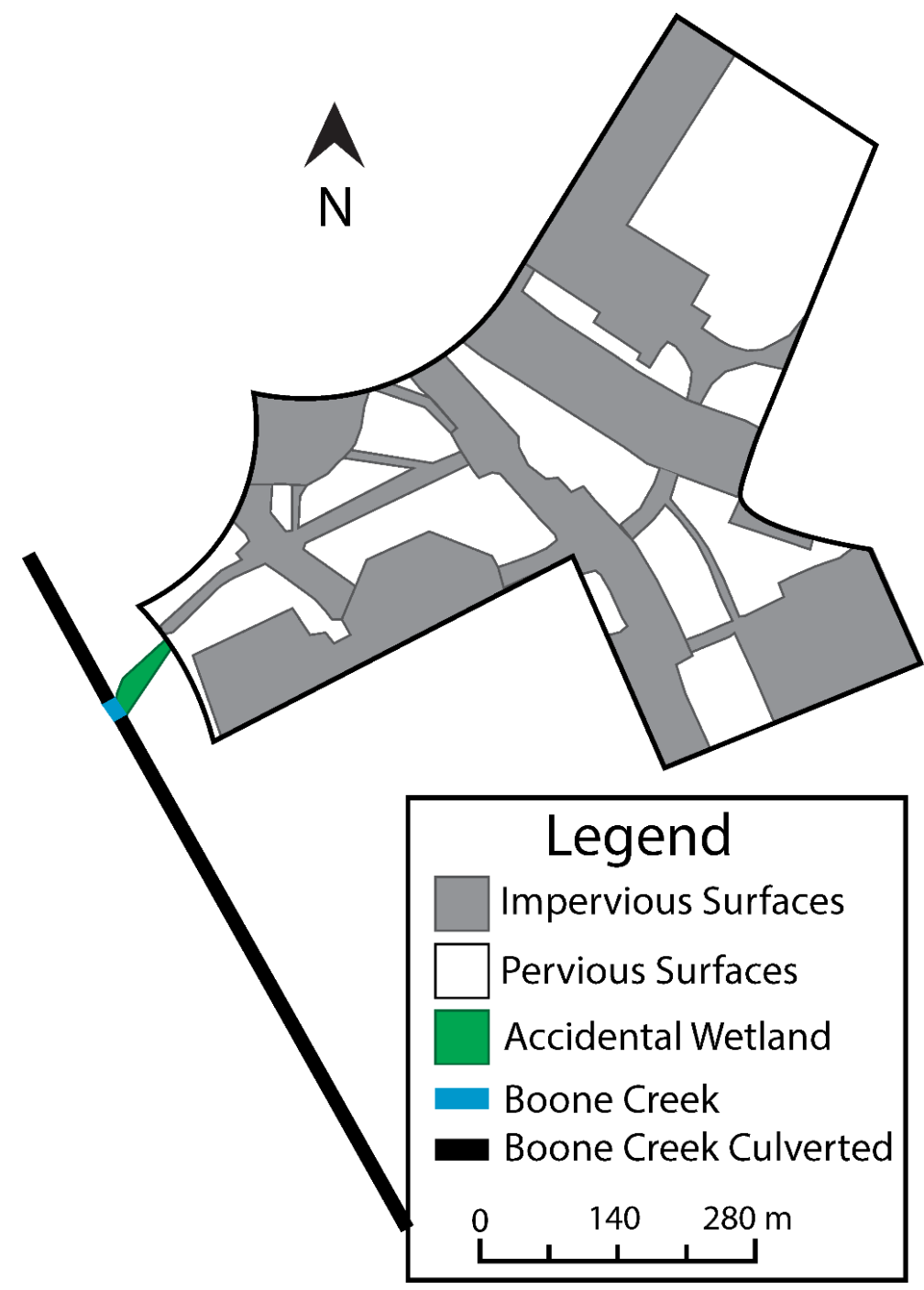

Figure 3. Total area of the drainage basin for the Accidental Wetland (AW) site. Gray areas indicate impervious surfaces such as sidewalks, roads, and rooftops and the white areas represent green spaces.
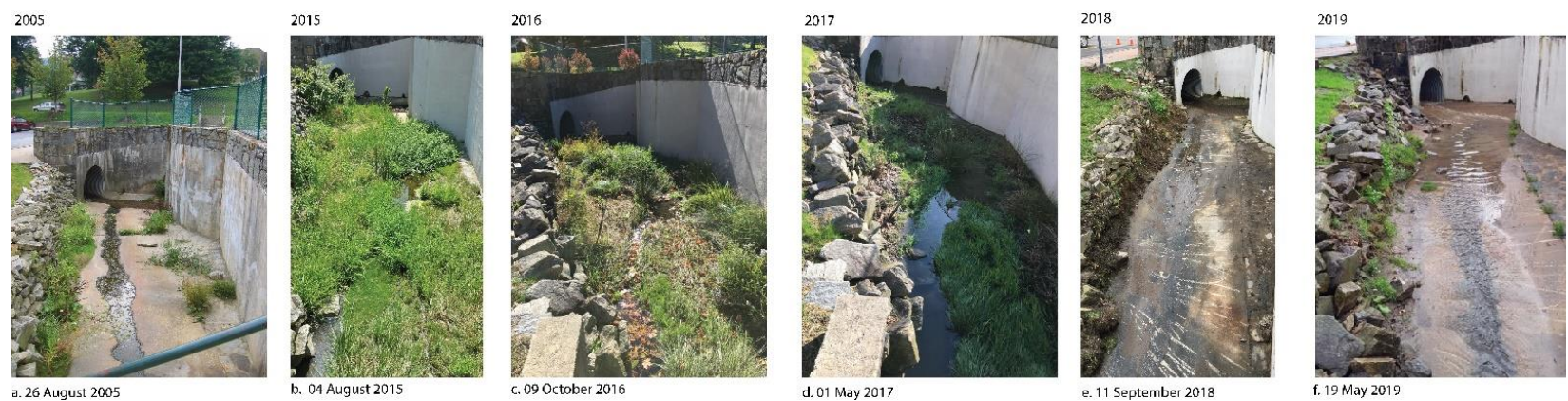

Figure 4. Evolution of the Accidental Wetland (AW) from 2005-2019. The photos were taken on the bridge over the wetland, facing downstream toward Boone Creek. The wetland was removed in September of 2018. 
The focus of this study was not on how accidental wetlands form, because the exact timing for this specific accidental wetland was unclear and did not factor in our findings. It may have originated in 2011-2012 from large storm events, carrying significant sediment into the culvert. By 2015, authors Anderson and Cockerill observed that the channel had become a heavily vegetated wetland (Figure $4 \mathrm{~b}$ ), and we began observing it regularly. Up to that point, we had paid little attention to the site and the few photos available before 2015 show spotty vegetation in 2005 (Figure 4a) and we observed some sediment accumulation along one edge by 2012. Since 2015 the system evolved to include diverse vegetation throughout the entire channel and a meandering "stream" through the vegetation.

A storm event in October 2017 deposited a large amount of sand/soil at the culvert end of the wetland. At that time, authors Maas and Anderson decided to assess what was happening more formally. They installed three wells and an electrical conductivity logger (HOBO Conductivity Data Logger, U24-001) along the length of the wetland in 2017. The monitoring wells showed large fluctuations in water levels throughout the year, with high levels during intense storm events during warm months and during the wet and cold winter. In September 2018 the university removed all of the vegetation and accumulated sediment in the accidental wetland as part of flood control measures on campus (Figure $4 \mathrm{e}, \mathrm{f}$ ).

\section{Materials and Methods}

\subsection{Field Data Collection}

We collected handheld probe measurements in the accidental wetland from 7 September 2017 through 6 February 2020. We used a Yellow Springs Instrument (YSI) 556 MPS (YSI, Yellow Springs, OH, USA) to measure salinity, dissolved oxygen, temperature, and other parameters. These data allowed us to gain an understanding of the salinity distribution within the wetland both spatially and temporally, and guided our conceptual model of transport through the sediment. For examples of studies using the YSI 556 MPS, see [36,37]. We collected handheld measurements on a regular basis at four locations along the wetland and at one location in Boone Creek (Figure 5). The YSI probe measured salinity in PSU, and we converted these data to equivalent chloride concentrations by multiplying by $606.6 \mathrm{mg} / \mathrm{L} \mathrm{Cl}^{-}$per PSU [38]. PSU is approximately equivalent to parts per thousand (ppt) of $\mathrm{NaCl}$; therefore, for every $1 \mathrm{~g} / \mathrm{L}$ of $\mathrm{NaCl}, 606.6 \mathrm{mg} / \mathrm{L}$ of the solution is $\mathrm{Cl}^{-}$and $393.4 \mathrm{mg} / \mathrm{L}$ is $\mathrm{Na}^{+}$[38]. All subsequent data in this study are presented in terms of equivalent chloride concentrations.

Datalogging at the Varsity Gym (VG) monitoring site has collected electrical conductivity (EC) data and stage-discharge data at 15-min intervals since July 2014, approximately $200 \mathrm{~m}$ downstream of the wetland (Figure 1). EC is a proxy for salinity [20]. The stream's salinity is less than that of the wetland due to the mixing of runoff after winter storm and precipitation events and the constant input of baseflow, which most often has a lower salinity than winter runoff. These data are scaled to provide a continuous dataset of boundary conditions for the groundwater flow and transport simulations, which are described later in the manuscript.

We used the Hazen method [39] on five soil samples collected from throughout the wetland to analyze grain size distributions. We used these data to estimate the accidental wetland's hydraulic conductivity using

$$
\mathrm{K}=\mathrm{C}\left(\mathrm{d}_{10}\right)^{2}
$$

where $\mathrm{d}_{10}$ is the diameter of the $10 \%$ finer grains $(\mathrm{cm})$ and $C$ is a coefficient based on grain size and sorting. We averaged the samples to estimate a bulk hydraulic conductivity for the wetland, and we further calibrated this value with subsequent numerical modeling experiments. 


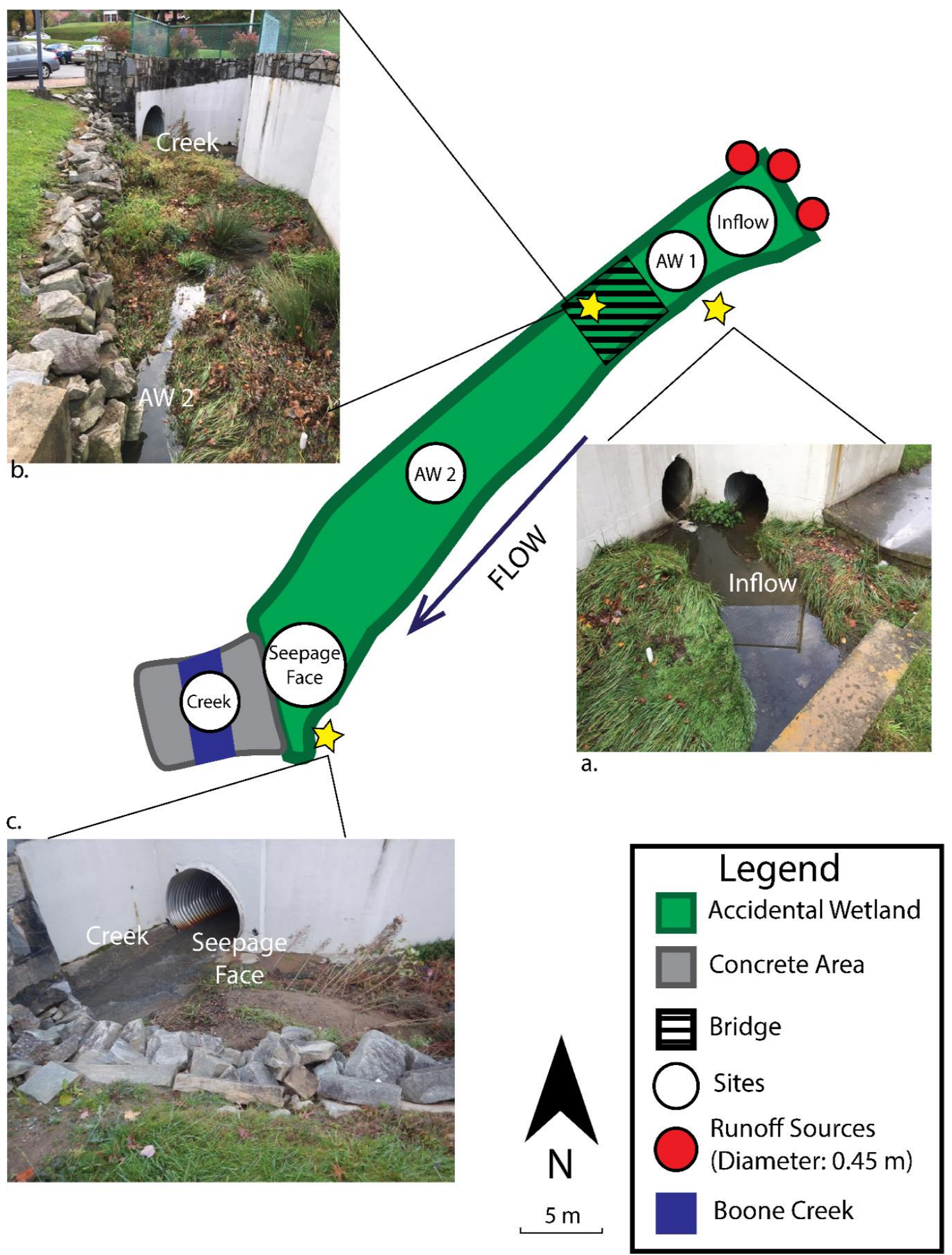

Figure 5. A map of the Accidental Wetland (AW). The stars indicate the locations from which the pictures were taken. Red circles indicate runoff surfaces at the inflow area of the wetland. The sites, denoted by white circles, were named Inflow, Accidental Wetland Site 1 (AW 1), Accidental Wetland Site 2 (AW 2), Seepage face, and Boone Creek. (a) Facing upstream towards the stormwater culverts, or the inflow sources. (b) Standing on bridge facing downstream towards seepage face and Boone Creek. (c) On grass facing Boone Creek stormwater culvert and the seepage face. The diameter of the culvert is $1.5 \mathrm{~m}$. 


\subsection{Numerical Modeling of Groundwater Flow and Solute Transport}

In this study, we used FEFLOW (DHI-WASY, DHI Group, Horsholm, Denmark) to simulate groundwater flow and solute transport through the wetland, utilizing salinity and runoff data from 2018 to formulate boundary conditions. FEFLOW is a three-dimensional finite-element groundwater flow and solute transport model that is well-documented in the literature and has been used to study subsurface solute transport (e.g., [40,41]). It has also been used in previous studies of the Boone Creek watershed [20]. The numerical model is not an attempt to recreate the empirical values collected from the accidental wetland through our sampling efforts; rather, the goal is to demonstrate with the model the groundwater flow and transport processes that are causing the decrease in salinity along the length of the wetland. The model does not account for any uptake of salt by the wetland plants or short-term retention by the wetland sediment, so the model output should be considered a conservative estimate of the effectiveness of the accidental wetland in delaying the arrival of salt-laden runoff.

Figure 6 shows the model domain that was used in groundwater flow and solute transport simulations for this study. The two-dimensional simulations represent a 21.2-meter-long by $0.2 \mathrm{~m}$ cross section of the accidental wetland. The base of the model is a no-flow boundary and represents the interface between the wetland and the concrete culvert. The stormwater inflow boundary at the right of the model domain, including two meters of the upper surface, is a time-dependent head and salinity boundary, the values of which are scaled to measurements taken at a long-term monitoring site on Boone Creek (see Figure 1 for the location of the Varsity Gym stream gauge relative to the accidental wetland). The seepage boundary on the left, representing the flow of water out of the wetland, is a time-dependent head boundary, with high water levels occurring only when a high stream stage in Boone Creek extends to the accidental wetland. A fluid flux boundary covers most of the top boundary of the model domain and represents the recharge to the mini-aquifer. Five simulated monitoring wells along the base of the model were used to collect output data for this paper. It was at these locations that we performed a semi-quantitative model calibration of our simulations to the field data.

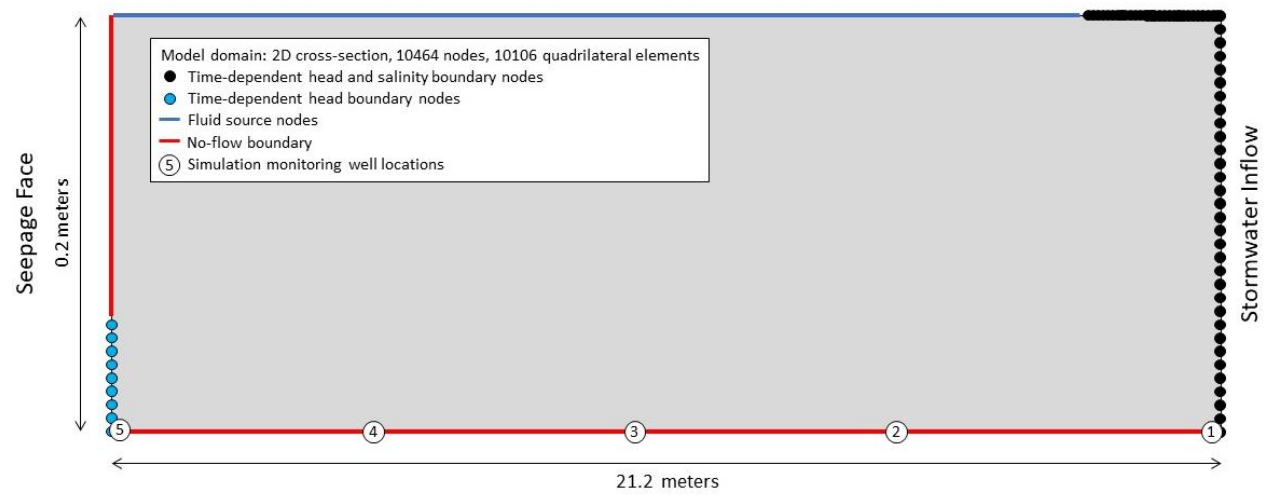

Figure 6. Model domain used in the flow and solute transport models. The flow enters on the right side of the figure, represented by black circles, and moves through the wetland to the seepage face in the left bottom corner, indicated by blue circles. The no-flow boundary (red line) represents the concrete culvert.

\section{Results}

\subsection{Field Data}

As shown in Figure 7, chloride values were highest at the upstream end of the wetland (at the inflow and AW1 and AW2 sites) and decreased with increasing distance into the accidental wetland. The highest salinities occurred at the first three sampling locations, and the lowest salinities left as discharge through the seepage face at the end of the accidental wetland (Table 1). As expected, the salinities decreased as the runoff moved downstream through the wetland, indicating that the wetland mitigated salinity by reducing peak 
values and delaying their arrival to the stream. About $47 \%$ of the time, the salinity at the seepage face was lower than the salinity at the inflow. This depended on the timing of the sampling because there may have been times when a fresh rainfall/runoff event occurred as a lagged salt event was still working its way through the wetland. Overall, however, as shown in Figure 7 and Table 1, the average and median chloride concentrations were highest at the upstream end of the wetland and were lowest at the downstream end of the wetland, near the seepage face.

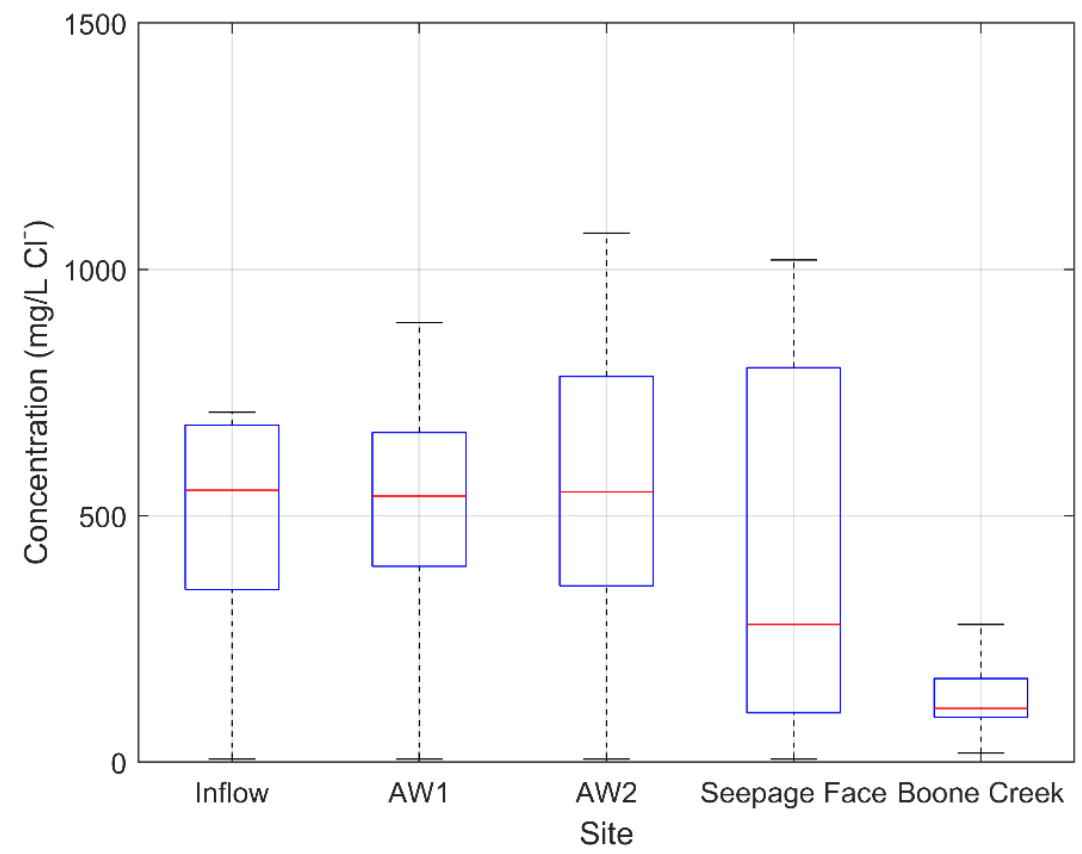

Figure 7. Boxplots of field chloride concentrations at each site throughout the length of the wetland. The middle red line marks the average chloride concentration. Chloride concentrations decrease towards the seepage face.

Table 1. Summary of chloride concentration statistics of the field measurements.

\begin{tabular}{|c|c|c|c|c|c|}
\hline & Inflow (mg/L Cl$\left.{ }^{-}\right)$ & AW1 (mg/L Cl-) & AW2 $\left(\mathrm{mg} / \mathrm{L} \mathrm{Cl}^{-}\right)$ & Seepage Face $\left(\mathrm{mg} / \mathrm{L} \mathrm{Cl}^{-}\right)$ & Boone Creek $\left(\mathrm{mg} / \mathrm{L} \mathrm{Cl}^{-}\right)$ \\
\hline Mean & 1637.7 & 1032.5 & 1060.2 & 316.3 & 254.3 \\
\hline Median & 552.0 & 539.9 & 539.9 & 48.5 & 109.2 \\
\hline STD & 3781.8 & 1995.7 & 1535.2 & 542.6 & 408.0 \\
\hline
\end{tabular}

\subsection{Synthetic Boundary Conditions}

Salinity data, collected at the inflow point to the AW, were collected with a handheld probe. Salinity data were also collected on a continual basis at the VG stream gauging site, just downstream of the AW. A comparison of these data suggests that salinity values at the AW inflow during melt events were 4.5 times greater than those measured at the VG site (Figure 8). Because we did not have continuous data from the AW inflow, we created a synthetic dataset of accidental wetland inflow salinities by taking the VG salinity data and multiplying those values by 4.5 (Figure 9). In doing so, we are acknowledging that we are not studying the exact conditions arriving at the AW, but are instead using a synthetic time series that is consistent with the observed salinities at the inflow point. These scaled salinities were used in the numerical model as the inflow boundary conditions. 


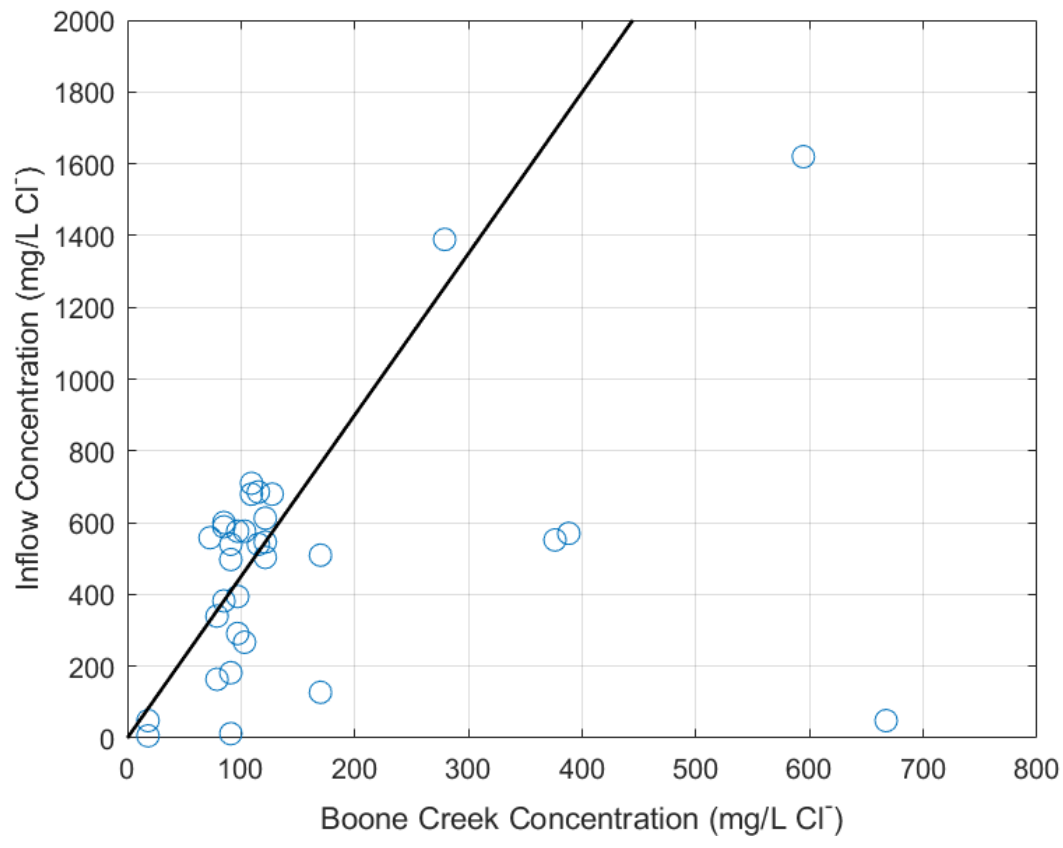

Figure 8. Relationship between the inflow concentrations of the Accidental Wetland and Boone Creek sites from hand samples. The black line represents the factor of 4.5 between the Boone Creek and inflow data. The open blue circles are the Boone Creek chloride concentration compared to inflow concentration collected during sampling.
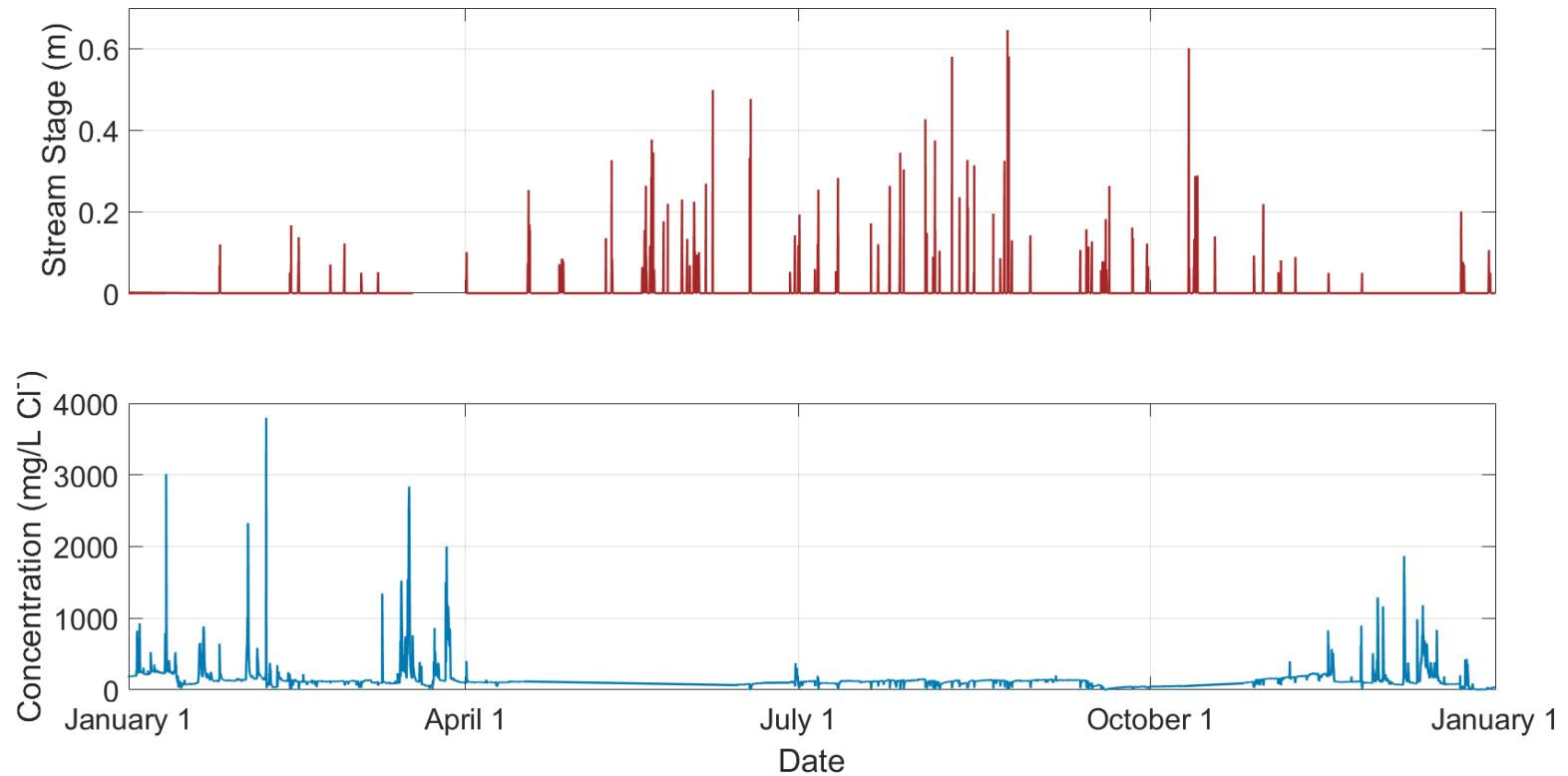

Figure 9. Stream stage-time plot (top panel) and concentration-time plot (bottom panel) from the Varsity Gym (VG) site from 1 January 2018 to 1 January 2019. The salinity data (bottom panel) were scaled by 4.5 to match concentrations observed in the Accidental Wetland and were used in the numerical model as inflow boundary conditions.

\subsection{Numerical Modeling of Groundwater Flow and Solute Transport}

The model output using the synthetic boundary condition data shows that the accidental wetland at the end of the stormwater culvert reduced peak salinity concentrations and delayed their arrival to Boone Creek. Dispersive transport properties in the wetland reduced peak salinity concentrations as the runoff water flowed as groundwater through the wetland. Here, groundwater refers to the flow of shallow subsurface water in the 
wetland substrate. There was no connection between the flow in the wetland and the natural water table due to the concrete culvert. The wetland groundwater velocities varied with the influx of water during storm and meltwater events. The gradients became high and in turn, increased the velocities, thus lowering the lag times; the storage of salt was of longer duration during dryer periods.

Initial simulations were carried out to examine the potential for a multi-year build-up of salt in the accidental wetland. To assess this, we ran a five-year simulation repeating our years' worth of scaled boundary data five times. Figure 10 shows the results of this simulation. The upper panel shows the scaled inflow data and the output seepage data. The lower panel shows the other simulated monitoring wells at a different vertical scale. The salinity concentration decreases through the wetland and approaches a concentration of zero during the summer months. The model output demonstrates that there is little, if any, salt accumulation in the wetland from season to season over the five years. This result is not surprising, given the small size of the wetland and the relatively fast circulation of water through the system.
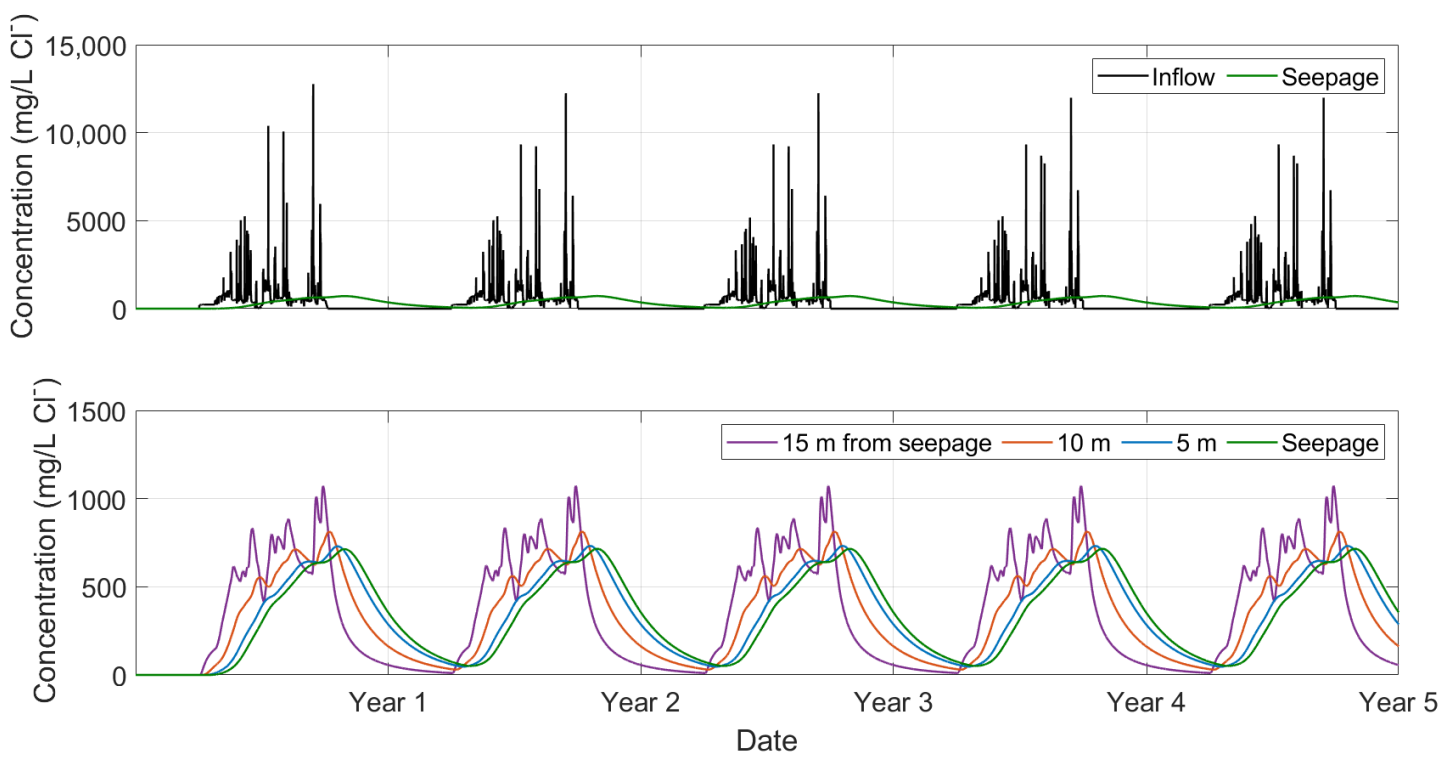

Figure 10. Concentration-time plots of output from the numerical model over five years of simulation time. The top panel shows the differences in salinity between the inflow to the wetland (black line) and the seepage face (dark green). The bottom panel shows the output from the simulated monitoring wells. Salinities decrease with distance travelled through the wetland, with the lowest salinities occurring at the seepage face.

Figure 11 shows simulation output, demonstrating the reduction in peak salinities as dispersion spreads out the salt plume with a transport distance downgradient. Figure 11 focuses on one year of the simulation output from Figure 10. It also demonstrates that there is a notable delay in the arrival of the center of mass of the plume to Boone Creek. The model output in the Figure compares the raw input data, represented by monitoring well 1 , to the output data of the seepage face. Peak salinity values at the inflow lag up to approximately 45 days and have a peak salinity reduction of up to $94 \%$ by the time the solute reaches the seepage face. These reduced salinities and delayed arrival times, caused by typical solute transport processes in the accidental wetland, prevent the stormwater culvert from being a source of the high-salinity surge that is typical of meltwater events during 'salt season.'

We also performed model sensitivity analyses to understand the effects of hydraulic conductivity, which we had only estimated from Hazen Method calculations and adjusted through model calibration, on modeled salinity concentrations at the seepage face. We varied hydraulic conductivity in the modeled wetland while keeping other parameters, such as boundary conditions and longitudinal and transverse dispersivities, equivalent 
to the base case scenarios. As expected, higher hydraulic conductivity values increase the groundwater velocity, which in turn results in a quicker pulse of salinity through the wetland system and higher seepage salinities (Figure 12). Solute transport processes suggest that macrodispersion increases with groundwater velocity; however, the small scale of the aquifer limits the time available for dispersion to take place, and the result is an advection-dominant transport process. For example, at a simulated hydraulic conductivity of $19.8 \mathrm{~m} / \mathrm{d}$, peak concentrations rise above $730 \mathrm{mg} / \mathrm{L} \mathrm{Cl}^{-}$and have a similar lag time to the base case simulation. Lower hydraulic conductivity values result in lower groundwater velocities, which increase the residence time of the salt in the aquifer. The low-permeability simulation, utilizing a hydraulic conductivity of $5 \mathrm{~m} / \mathrm{d}$, lagged the other sensitivity simulations by three months and had a peak concentration of roughly half of the base and high-permeability simulations.
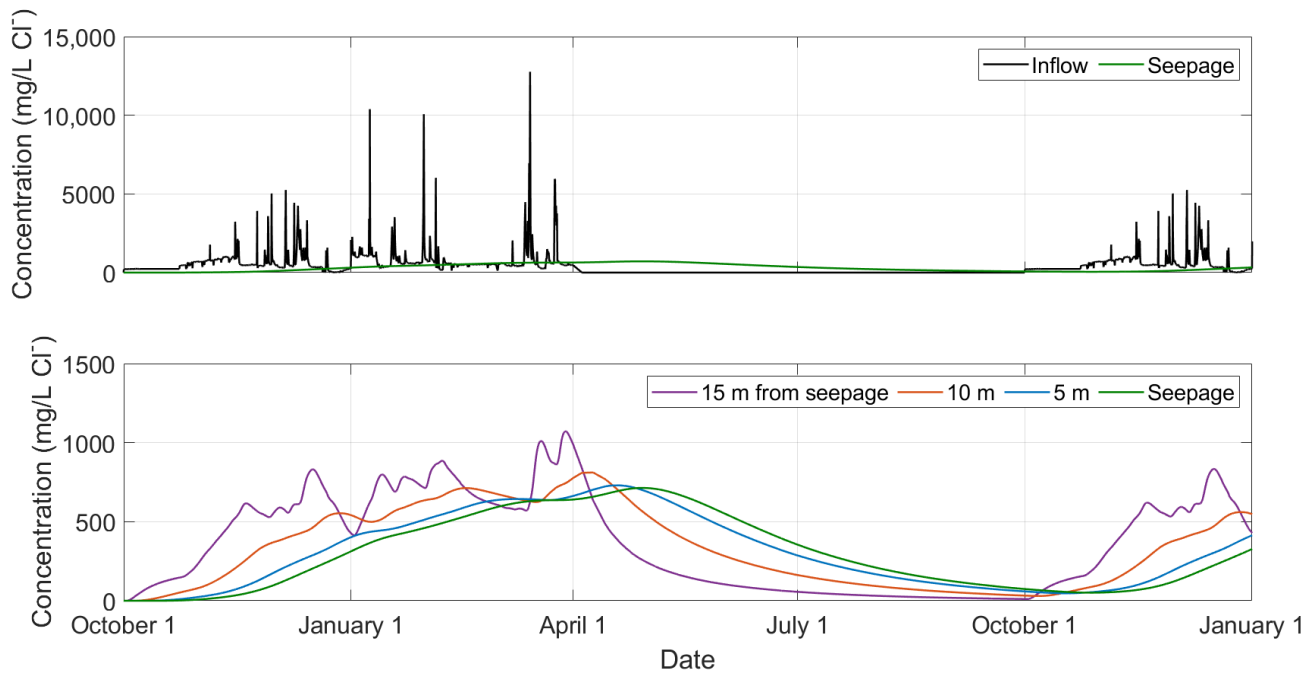

Figure 11. Concentration-time plot from the start of the typical salt season to show the mitigation of salt from the inflow to the seepage face. The top panel plots the inflow (black line) and seepage face (dark green line) salinities. The bottom panel plots the salinities of the different monitoring wells from the numerical model. Closer to the seepage face, lower salinities can be observed.

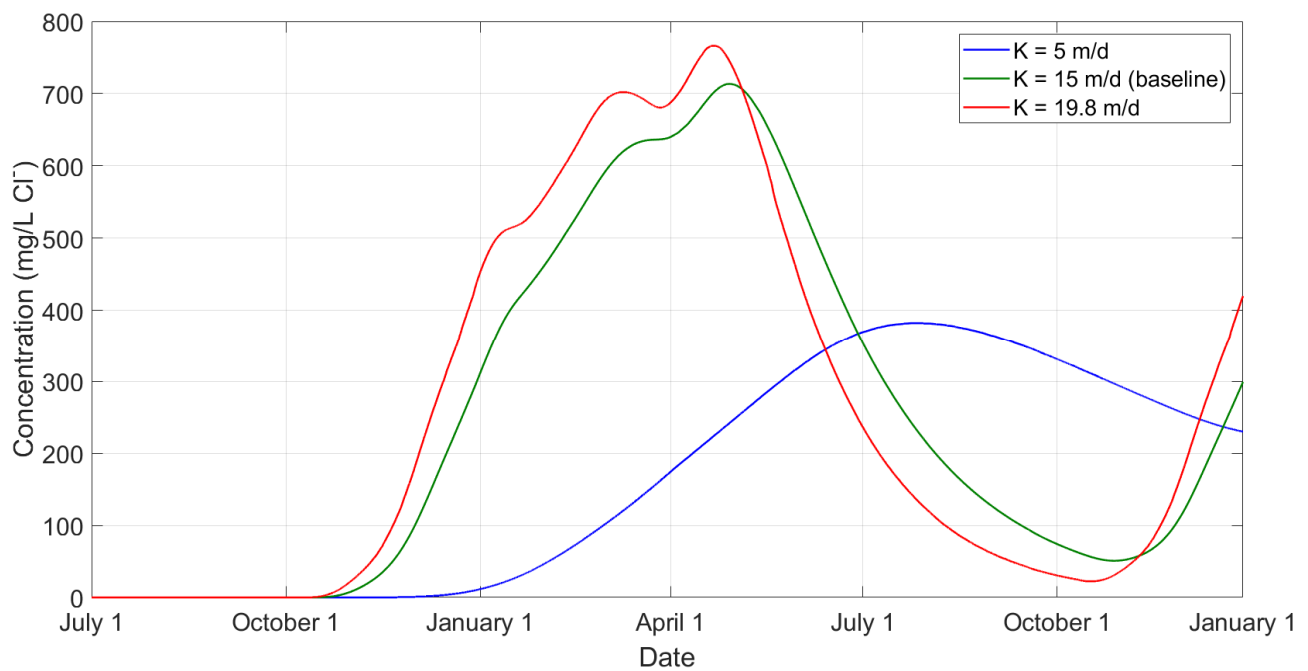

Figure 12. Concentration-time plot for the sensitivity analysis of the numerical model of salinities at the seepage face. $\mathrm{K}=15 \mathrm{~m} / \mathrm{d}$ (dark green) was the hydraulic conductivity used in the above simulations. The model is sensitive to changes in hydraulic conductivity. 


\section{Discussion}

Our study demonstrates that accidental wetlands help remediate salt-laden stormwater runoff by increasing the residence time of the salt and delaying its arrival to a receiving stream, thereby decreasing the peak concentration of the salinity pulse but not the overall quantity of salt that is delivered to the stream.

Our field-sampled data support this conclusion. The median and mean values at the seepage face at the end of the wetland were lower in concentration than those at the upper end of the wetland, where salt-rich runoff entered the wetland during salt events. Our groundwater modeling and solute transport simulations also support this conclusion in a comprehensive way. The accidental wetland slows the delivery of salt-laden runoff, thereby lowering simulated salinities by up to 94 percent and lagging the timing of the peak concentrations by up to 45 days. This type of retention system does not remove the salt, but by slowing down its migration to the adjacent stream, it can lower the chance of chronic chloride violations and greatly reduce the potential for acute salinity spikes. This distinction between acute and chronic is important to stream health in the same way that dosage is relevant to any toxin. As noted previously, in their review of salinity impacts, Hintz and Relyea [17] found significant variability across species and across salinity levels. For example, they found that some species adapt to chronic salinity levels, although acute spikes are lethal. Because road salt will continue to enter streams, finding ways to at least lower the intense spikes of salt should be beneficial. If enough accidental wetlands are encouraged within urban watersheds, rather than removed from them, this could have a positive influence on the overall water quality in streams.

Furthermore, sensitivity analyses with the model showed that hydraulic conductivity values typical of sands are ideal in order for this to take place. This was the primary material in the accidental wetland at our study site and served as the base case for our simulations. It is safe to assume, however, that materials with properties too far outside of this range, such as gravels or clays, would not be effective. The hydraulic conductivity of highly-permeable materials such as gravels would allow rapid migration through the accidental wetland, preventing much of a reduction in peak concentrations or an increase in lag times. Conversely, silts and clays would have so little permeability that surface flow would dominate and would allow the quick delivery of the salt-laden urban runoff to the stream.

We think that there are likely other accidental wetlands similar to the one studied here in other environments; that is, a small scale, concrete substrate wetland forming in an area "designed" for another purpose. The formation of multiple accidental wetlands along a watershed would retain a higher percentage of the road salt, thus decreasing the concentration of the salinity pulses and preventing higher salinities in streams themselves. We can potentially improve the water quality of our urban streams by watching for and then encouraging accidental wetlands in multiple areas throughout a watershed.

\subsection{Other Accidental Benefits}

In addition to salinity concerns, accidental wetlands also influence other dynamic hydraulic issues such as stream flashiness and temperature surges in urban environments. Stream flashiness is caused by high percentages of impervious surfaces in the watershed, especially in the lower reaches in the Town of Boone and on the ASU campus, and results in rapid stream-stage increases and reversed-gradient events, which drive road salt into riparian aquifers along the length of urban stream reaches. These processes lead to both chronic and acute stream contamination over much longer time frames than what occurs in natural, unurbanized streams [42]. In our study location, urban, flashy runoff provides a significant source of contamination to the riparian aquifer along Boone Creek, a focus of years of urban hydrology research, and these groundwater-surface water interaction processes are especially important in relation to the chronic and acute chloride contamination of Boone Creek. 
When stormwater runoff encounters an accidental wetland, the amount of runoff entering the stream decreases and lags according to the travel time that the wetland requires. Temperature surges occur when heated runoff enters a stream and quickly increases the stream temperature [20]. Depending on the formation of the accidental wetland, any detained water has time to cool, thereby reducing the temperature of hot runoff in temperature surges. If enough of these wetlands form, temperature surges will perhaps be greatly reduced or eliminated within a watershed. Long-term average stream temperatures are also improved by accidental wetlands via natural shading [3]; in fact, several small trees, along with other knee-high vegetation, did grow in the accidental wetland we studied. In addition to reducing impacts from salt, our case suggests that accidental wetlands in urban areas can reduce the effects of urban stream syndrome by mitigating flashiness and heat.

\subsection{Management Implications}

As already noted, campus facilities management removed the accidental wetland in 2018. Removing this wetland aligns with historic management approaches as well as continued perceptions about stormwater, flooding, and vegetated waterways. Traditional stormwater management has focused on shunting water as quickly as possible to the nearest stream to avoid flooding. Although new approaches, including constructing wetlands, bioswales, and retention systems, have been implemented, there remains a lack of understanding and misperceptions about these kinds of management techniques. In his overview of the literature, Everett [43] concluded that while there is some public awareness of alternative management approaches, it is not yet mainstream knowledge. People tend to focus on the amenity value or the aesthetics of entities like wetlands or bioswales rather than on their function. In some cases, this creates a negative feedback loop, in which people do not understand what the infrastructure is designed to do-or in this case what it accidentally does-and they therefore do not manage or maintain it appropriately, which leads to further negative views as aesthetics and/or function decline.

In our Boone Creek case, a misperception that the wetland was reducing the channel's ability to handle runoff and thereby increasing flooding risk was the rationale to remove it. This mistaken perception potentially reduced, rather than improved, both flood management and water quality. Because all of the vegetation and sediment was removed, runoff entering the culvert now goes straight into the stream, carrying any salt with it (Figure 2f). Because accidental wetlands arise without intention and are not part of explicit management plans, they can be ephemeral and can be quickly removed. If paying attention to when and where accidental wetlands form became part of overall urban stormwater management and planning, it could offer reduced flooding, improved water quality, and economic benefits, as the wetland costs nothing to establish.

\section{Conclusions}

The accidental formation of a wetland in a cold, urban environment inspired us to study the impacts of this system on mitigating road salt. Returning to our research questions for this conceptual study, we conclude that the accidental wetland decreased the peak concentrations of salt and chloride contamination and delayed the arrival of salt to the stream. Simple numerical simulations demonstrated that the saline pulse from urban runoff was delayed by up to 45 days and peak concentrations declined by up to $94 \%$. Although the salt is not removed from the system, its arrival was delayed and the peak concentrations were lowered, ultimately improving water quality and potentially reducing negative consequences for some aquatic species.

We also think that accidental wetlands are likely to serve several functions and potentially offer multiple benefits to stream quality. For example, our model provided a conservative estimate regarding peak salinity reduction because we did not include uptake by plants. Future research assessing the role of vegetation and/or soil in contributing to reducing salinity impacts in accidental wetlands is warranted. Additionally, our results 
suggest that accidental wetlands may be effective in lowering runoff-induced thermal pollution due to the delay in the runoff entering the stream. Although this delay does not actually remove the salt, it most likely does reduce the temperature, offering a potentially significant improvement in cold-water streams. Again, more detailed analyses of this potential contribution from accidental wetlands would be valuable. Our work highlights the potential for accidental wetlands to improve water quality issues in urban streams. The only way to decrease salinization issues in cold regions is to discontinue the use of road salt during winter storm events. Because of safety concerns, totally eliminating salt is not practicable and therefore, we need to better understand and explore reactive measures to retain salt and delay its delivery into streams. Our study builds on previous work, suggesting that accidental wetlands cost nothing but offer multiple benefits, which are potentially as valuable as some stream restoration or intentional stormwater retention measures.

Author Contributions: Conceptualization, C.M.M. and W.P.A.J., methodology, C.M.M. and W.P.A.J.; software, C.M.M. and W.P.A.J.; validation, C.M.M., W.P.A.J., and K.C.; formal analysis, C.M.M. and W.P.A.J.; investigation, C.M.M. and W.P.A.J.; resources, C.M.M. and W.P.A.J.; data curation, C.M.M. and W.P.A.J.; writing-original draft preparation, C.M.M. and W.P.A.J.; writing—review and editing, C.M.M., W.P.A.J., and K.C.; visualization, C.M.M. and W.P.A.J.; supervision, W.P.A.J. and K.C.; project administration, W.P.A.J. and K.C.; funding acquisition, C.M.M. and W.P.A.J. All authors have read and agreed to the published version of the manuscript.

Funding: This research received no external funding.

Institutional Review Board Statement: Not applicable.

Informed Consent Statement: Not applicable.

Data Availability Statement: Data are contained within the article and more detailed data may be requested from the authors.

Acknowledgments: The authors thank the Department of Geological and Environmental Sciences, the College of Arts and Science, and the Office of Student Research at Appalachian State University for support of the work. We thank undergraduate researchers Emily Fedders and Andrew Barringer for their help in maintaining the stream monitoring network. We also thank the comments and suggestions of four reviewers of a previous version of this paper.

Conflicts of Interest: The authors declare no conflict of interest.

\section{References}

1. Suchy, A. Denitrification in Accidental Urban Wetlands: Exploring the Roles of Water Flows and Plant Patches. Available online: https:/ / core.ac.uk/download/pdf/79587123.pdf (accessed on 11 November 2020).

2. Sueltenfuss, J.P.; Cooper, D.J.; Knight, R.L.; Waskom, R.M. The Creation and Maintenance of Wetland Ecosystems from Irrigation Canal and Reservoir Seepage in a Semi-Arid Landscape. Wetlands 2013, 33, 799-810. [CrossRef]

3. Palta, M.M.; Grimm, N.B.; Groffman, P.M. "Accidental” Urban Wetlands: Ecosystem Functions in Unexpected Places. Front. Ecol. Environ. 2017, 15, 248-256. [CrossRef]

4. Brooks, B.W.; Riley, T.M.; Taylor, R.D. Water Quality of Effluent-Dominated Ecosystems: Ecotoxicological, Hydrological, and Management Considerations. Hydrobiologia 2006, 556, 365-379. [CrossRef]

5. Scheffers, B.R.; Paszkowski, C.A. Amphibian Use of Urban Stormwater Wetlands: The Role of Natural Habitat Features. Landsc. Urban Plan. 2013, 113, 139-149. [CrossRef]

6. $\quad$ Bateman, H.L.; Stromberg, J.C.; Banville, M.J.; Makings, E.; Scott, B.D.; Suchy, A.; Wolkis, D. Novel Water Sources Restore Plant and Animal Communities along an Urban River. Ecohydrology 2015, 8, 792-811. [CrossRef]

7. Downing, J.A. Emerging global role of small lakes and ponds: Little things mean a lot. Limnética 2010, $29,9-24$.

8. Van Meter, K.J.; Basu, N.B. Signatures of Human Impact: Size Distributions and Spatial Organization of Wetlands in the Prairie Pothole Landscape. Ecol. Appl. 2015, 25, 451-465. [CrossRef]

9. Suchy, A.K.; Palta, M.M.; Stromberg, J.C.; Childers, D.L. High Potential Nitrate Removal by Urban Accidental Wetlands in a Desert City: Limitations and Spatiotemporal Patterns. Ecosystems 2020, 23, 1227-1242. [CrossRef]

10. Palta, M. Urban "Accidental” Wetlands Mediate Water Quality and Heat Exposure for Homeless Populations in a Desert City. AGU Fall Meet. Abstr. 2015, 21, H21J-1528. Available online: https://ui.adsabs.harvard.edu/abs/2015AGUFM.H21J1528P/abstract (accessed on 10 November 2020).

11. Atkinson, R.B.; Cairns, J. Possible Use of Wetlands in Ecological Restoration of Surface Mined Lands. J. Aquat. Ecosyst. Stress Recov. 1994, 3, 139-144. [CrossRef] 
12. Gu, C.; Cockerill, K.; Anderson, W.P.; Shepherd, F.; Groothuis, P.A.; Mohr, T.M.; Whitehead, J.C.; Russo, A.A.; Zhang, C. Modeling Effects of Low Impact Development on Road Salt Transport at Watershed Scale. J. Hydrol. 2019, 574, 1164-1175. [CrossRef]

13. Jin, L.; Whitehead, P.; Siegel, D.I.; Findlay, S. Salting Our Landscape: An Integrated Catchment Model Using Readily Accessible Data to Assess Emerging Road Salt Contamination to Streams. Environ. Pollut. 2011, 159, 1257-1265. [CrossRef] [PubMed]

14. Kelly, V.R.; Lovett, G.M.; Weathers, K.C.; Findlay, S.E.G.; Strayer, D.L.; Burns, D.J.; Likens, G.E. Long-Term Sodium Chloride Retention in a Rural Watershed: Legacy Effects of Road Salt on Streamwater Concentration. Environ. Sci. Technol. 2008, 42, 410-415. [CrossRef] [PubMed]

15. Lilek, J. Roadway Deicing in the United States. Available online: https:/ /www.americangeosciences.org/geoscience-currents/ roadway-deicing-united-states (accessed on 11 November 2020).

16. Kelly, V.R.; Cunningham, M.A.; Curri, N.; Findlay, S.E.; Carroll, S.M. The Distribution of Road Salt in Private Drinking Water Wells in a Southeastern New York Suburban Township. J. Environ. Qual. 2018, 47, 445-451. [CrossRef] [PubMed]

17. Hintz, W.D.; Relyea, R.A. A Review of the Species, Community, and Ecosystem Impacts of Road Salt Salinisation in Fresh Waters. Freshw. Biol. 2019, 64, 1081-1097. [CrossRef]

18. Burgis, C.R.; Hayes, G.M.; Henderson, D.A.; Zhang, W.; Smith, J.A. Green Stormwater Infrastructure Redirects Deicing Salt from Surface Water to Groundwater. Sci. Total Environ. 2020, 729, 138736. [CrossRef]

19. Oswald, C.J.; Giberson, G.; Nicholls, E.; Wellen, C.; Oni, S. Spatial Distribution and Extent of Urban Land Cover Control Watershed-Scale Chloride Retention. Sci. Total Environ. 2019, 652, 278-288. [CrossRef]

20. Cockerill, K.; Anderson, W.P.; Harris, F.C.; Straka, K. Hot Salty Water: A Confluence of Issues in Managing Stormwater Runoff for Urban Streams. JAWRA J. Am. Water Resour. Assoc. 2017, 53, 707-724. [CrossRef]

21. Kratky, H.; Li, Z.; Chen, Y.; Wang, C.; Li, X.; Yu, T. A Critical Literature Review of Bioretention Research for Stormwater Management in Cold Climate and Future Research Recommendations. Front. Environ. Sci. Eng. 2017, 11, 16. [CrossRef]

22. Barbier, L.; Suaire, R.; Durickovic, I.; Laurent, J.; Simonnot, M.-O. Is a Road Stormwater Retention Pond Able to Intercept Deicing Salt? Water Air Soil Pollut. 2018, 229, 251. [CrossRef]

23. Fanelli, R.M.; Prestegaard, K.L.; Palmer, M.A. Urban Legacies: Aquatic Stressors and Low Aquatic Biodiversity Persist despite Implementation of Regenerative Stormwater Conveyance Systems. Freshw. Sci. 2019, 38, 818-833. [CrossRef]

24. Cooper, C.A.; Mayer, P.M.; Faulkner, B.R. Effects of Road Salts on Groundwater and Surface Water Dynamics of Sodium and Chloride in an Urban Restored Stream. Biogeochemistry 2014, 121, 149-166. [CrossRef]

25. Søberg, L.C.; Viklander, M.; Blecken, G.-T. Do Salt and Low Temperature Impair Metal Treatment in Stormwater Bioretention Cells with or without a Submerged Zone? Sci. Total Environ. 2017, 579, 1588-1599. [CrossRef] [PubMed]

26. Lange, K.; Österlund, H.; Viklander, M.; Blecken, G.-T. Metal Speciation in Stormwater Bioretention: Removal of Particulate, Colloidal and Truly Dissolved Metals. Sci. Total Environ. 2020, 724, 138121. [CrossRef]

27. Taguchi, V.J.; Weiss, P.T.; Gulliver, J.S.; Klein, M.R.; Hozalski, R.M.; Baker, L.A.; Finlay, J.C.; Keeler, B.L.; Nieber, J.L. It Is Not Easy Being Green: Recognizing Unintended Consequences of Green Stormwater Infrastructure. Water 2020, 12, 522. [CrossRef]

28. Brydon, J.; Roa, M.C.; Brown, S.J.; Schreier, H. Integrating Wetlands into Watershed Management: Effectiveness of Constructed Wetlands to Reduce Impacts from Urban Stormwater. In Proceedings of the Environmental Role of Wetlands in Headwaters; Krecek, J., Haigh, M., Eds.; Springer: Dordrecht, The Netherlands, 2006; pp. 143-154.

29. Mangangka, I.R.; Egodawatta, P.; Parker, N.; Gardner, T.; Goonetilleke, A. Performance Characterisation of a Constructed Wetland. Water Sci. Technol. 2013, 68, 2195-2201. [CrossRef]

30. Land, M.; Granéli, W.; Grimvall, A.; Hoffmann, C.C.; Mitsch, W.J.; Tonderski, K.S.; Verhoeven, J.T.A. How Effective Are Created or Restored Freshwater Wetlands for Nitrogen and Phosphorus Removal? A Systematic Review. Environ. Evid. 2016, 5, 9. [CrossRef]

31. Zu Ermgassen, S.O.S.E.; Baker, J.; Griffiths, R.A.; Strange, N.; Struebig, M.J.; Bull, J.W. The Ecological Outcomes of Biodiversity Offsets under "No Net Loss" Policies: A Global Review. Conserv. Lett. 2019, 12, e12664. [CrossRef]

32. Copeland, S. On Serendipity in Science: Discovery at the Intersection of Chance and Wisdom. Synthese 2019, 196, 2385-2406. [CrossRef]

33. Rice, J.S.; Anderson, W.P., Jr.; Thaxton, C.S. Urbanization Influences on Stream Temperature Behavior within Low-Discharge Headwater Streams. Hydrol. Res. Lett. 2011, 5, 27-31. [CrossRef]

34. NC DEQ: Classifications. Available online: https://deq.nc.gov/about/divisions/water-resources/planning/classificationstandards/classifications\#DWRPrimaryClassification (accessed on 19 November 2020).

35. Benoit, D. Ambient Water Quality Criteria for Chloride—1988; EPA: Washington, DC, USA, 1988; Volume 988, p. 47.

36. Yu, Z.; Qi, Z.; Hu, C.; Liu, W.; Huang, H. Effects of Salinity on Ingestion, Oxygen Consumption and Ammonium Excretion Rates of the Sea Cucumber Holothuria Leucospilota. Aquac. Res. 2013, 44, 1760-1767. [CrossRef]

37. Stringer, C.E.; Rains, M.C.; Kruse, S.; Whigham, D. Controls on Water Levels and Salinity in a Barrier Island Mangrove, Indian River Lagoon, Florida. Wetlands 2010, 30, 725-734. [CrossRef]

38. Palmer, J.J. How to Brew: Everything You Need to Know to Brew Great Beer Every Time; Brewers Publications: Kent, OH, USA, 2017; ISBN 978-1-938469-35-0.

39. Hazen, A. Discussion of Dams on Sand Foundations by A. C. Koenig. Trans. Am. Soc. Civ. Eng. 1911, 73, $199-203$.

40. Trefry, M.G.; Muffels, C. FEFLOW: A Finite-Element Ground Water Flow and Transport Modeling Tool. Groundwater 2007, 45, 525-528. [CrossRef]

41. Sivakumar, C.; Elango, L. Application of Solute Transport Modeling to Study Tsunami Induced Aquifer Salinity in India. J. Sci. Technol. Environ. 2010, 15, 33-41. [CrossRef] 
42. Anderson, W.P.; Storniolo, R.E.; Rice, J.S. Bank Thermal Storage as a Sink of Temperature Surges in Urbanized Streams. J. Hydrol. 2011, 409, 525-537. [CrossRef]

43. Everett, G. Public Perceptions of Sustainable Drainage Devices. In Sustainable Surface Water Management; John Wiley \& Sons, Ltd.: Hoboken, NJ, USA, 2016; pp. 285-297, ISBN 978-1-118-89769-0. 